\begin{tabular}{|c|c|c|}
\hline & Int.J.Curr.Microbiol.App.Sci (2021) 10(09): 216-229 & \\
\hline & $\begin{array}{l}\text { International Journal of Current Microbiology and Applied Sciences } \\
\text { ISSN: 2319-7706 Volume } 10 \text { Number } 09 \text { (2021) } \\
\text { Journal homepage: http://www.ijcmas.com }\end{array}$ & 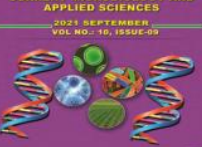 \\
\hline $\begin{array}{l}\text { EXCELLENT } \\
\text { PUBLISHERS }\end{array}$ & & \\
\hline
\end{tabular}

\title{
Biodegradable Sheet from Chitosan and Arrowroot Starch by Compression Moulding and its Properties
}

\author{
Abhirup Mitra* and Genitha Immanuel \\ Department of Food Process Engineering, Sam Higginbottom University of Agriculture, \\ Technology and Sciences, Prayagraj, UP-211007, India \\ *Corresponding author
}

Keywords

Thermoplastic

Starch,

Thermoplastic

chitosan,

biodegradability

Article Info

Accepted:

10 August 2021

Available Online:

10 September 2021
This research work entitled preparation and properties evaluation of biodegradable sheet from arrowroot starch and chitosan. It was carried out through compression moulding method by using Arrowroot starch, Chitosan, Glycerol, Citric acid, water. Functional properties like Tensile strength, Elongation at break (\%), biodegradability were evaluated. There were two treatments $\mathrm{T} 1$ and $\mathrm{T} 2$ with varying composition of arrowroot starch and chitosan. Tensile strength was observed as 4.80MPA (T1) and 3.74 MPA (T2). Elongation at break \% was $155.6 \%$ (T1) and 203.3\% (T2). Soil burial method was used for evaluation of biodegradability of sheet. T2 had better percentage of decomposition in 30 days. The biodegradable sheet can be used for various packaging applications and safety to environment as they are biodegradable.

\section{Introduction}

It is widely believed that plastics do not biodegrade due to its synthetic polymers which is not easily and apt degraded; eventually which affects environment and living beings. This creates an urge for a better alternative which is easily degradable by organism, and thus emerged the concept of biodegradable plastics and polymers which was first introduced in the 1980s. Biodegradable polymer decomposes through the action of living organisms, usually bacteria. There are two types of biodegradable plastics: bio plastics, plastics that are derived from renewable raw materials such as poly-3hydroxybutyrate (PHB) and polyhydroxyvalerate (PHV) and plastics that contain 
biodegradable additives. The latter are derived from petrochemicals and contain additives that enhance biodegradation. Biodegradable polymers are a specific type of polymer that results in by-products such as $\mathrm{CO}_{2}, \mathrm{~N}_{2}, \mathrm{H}_{2}$ $\mathrm{O}$, biomass and inorganic salts when they break down.

These plastics are found both naturally and synthetically and consist largely of ester, amide and ether groups. How they breakdown is determined by their structure and is often synthesized by condensation reactions as well as ring opening polymerization. Biodegradable plastics are made from starch, cellulose, chitin, and protein extracted from renewable biomass (Azahari et al., 2011). The development of most bio plastic is assumed to reduce fossil fuel usage, and plastic waste, as well as carbon dioxide emissions. The biodegradability characteristics of these plastics create a positive impact in society, and awareness of biodegradable packaging also attracts researchers and industries (Siakeng et al., 2019). Bio plastics may be openly taken out from natural resources like lignins, proteins, lipids, and polysaccharides (e.g., starch, chitin, and cellulose) (Johansson et al., 2012). Approximately $50 \%$ of the bio plastics used commercially are prepared from starch.

Chitosan is obtained by deacetylation of chitin. Chitin is present in the exoskeleton of many marine invertebrates, insects, some algae and mucoraceous fungi. However, despite the wide range of sources for chitin extraction; it is mainly obtained from crustacean shells, a major waste in various food and fish industries (Leceta et al., 2014). Furthermore, with the objective of developing a more sustainable way of waste management, waste valorization techniques have received significant attention in the last years with an emerging interest to use crustacean shell wastes as an attractive source of chitosan (Leceta et al., 2015).
Starch is a biodegradable and thermoplastic polymer formed mainly by two polysaccharides: amylose and amylopectin. In recent research, this polymer is considered to be a promising agent for applications such as food packaging due to its biodegradability, flexibility and its hypoallergenic quality, which makes it an appropriate material for food industry utilization. Starch from arrowroot was used in this research, which is a less studied starch source. Arrowroot starch is cheaper and easily available in anywhere. Arrowroot powder or starch extracted from the root of a tropical plant known as Maranta arundinacea.

\section{Justification}

Every year, millions of tons of plastic are discarded into landfills, where they will take hundreds of years to break down. In addition to being land filled, some plastic is disposed of improperly, leading to plastic pollution on land and in lakes and oceans where they persist. Once in the environment, animals can accidentally eat the plastic but are incapable of digesting it, so the plastic just sits in their stomachs. Over time, the plastic can block off their digestive system, and the animal will starve. Biodegradable plastics offer a potential solution to this problem. One of the main advantages of using biodegradable polymers to make films or sheets is the significant reduction in the carbon emissions that happen during the manufacturing process as compared to that of regular plastic. Avoiding migration of polymer compound into packaged food is also a big issue. Motivation of this research is to synthesize of biodegradable and biocompatible packaging sheet to replace the petroleum based polymer for packaging of foods. The ultimate aim was to make the biodegradable sheet by compression moulding successfully and to achieve the maximum degradability, sustainability by combining or fusioning arrowroot starch with chitosan. 
Chitosan is natural polymer found in the exoskeletons of insects, the cell wall of fungi and hard structure of invertebrates, fish, egg shell etc in the form of chitin, which is insoluble in organic solvents, that's why removal of acetyle group is necessary which leads to the conversion in chitosan. Chitosan is biocompatible, biodegradable, and edible and it also has great antimicrobial property too and on other hand starch is also a biodegradable polymer and arrowroot powder is a great source of starch. It can be available anywhere.

\section{Materials and Methods}

\section{Method of Sheet Preparation}

Preparation of biodegradable packaging sheet by compression moulding was carried out by below mentioned process according to Lopez et al., 2014 with some modifications according to the availability of infrastructure. Complete process is explained with the help of flow diagram.

The biodegradable sheets of two different proportions were obtained by compression moulding method. At the beginning stage, All the chemicals i.e. chitosan, Arrowroot starch, Talc powder, Citric acid and glycerol were weighed as per the required proportions and then mixed with the help of glass rod. After that the mixture was conditioned at $25^{\circ} \mathrm{C}$ of temperature for next $28 \mathrm{~h}$. Then the mixture was heated with the help of hot plate by continuous stirring by glass rod up to 15 minutes and the temperature was maintained in between $135-140^{\circ} \mathrm{C}$. At the time of heating and stirring the temperature is also checked simultaneously by digital thermometers so that the temperature not increase or decrease than the given range. After continuous heating and stirring operation the mixture became slightly sticky in nature. Then the mixture was stored again for next one week at $25^{\circ} \mathrm{C}$ temperature. After one week the mixture was taken out for final stage at which it placed in between the mould in a thin layer and then it placed into the preheated chamber $\left(135^{\circ}-155^{\circ} \mathrm{C}\right)$ of compression moulding machine. Then the pressure lever was pulled down on the mould and the pressure set at 25 bar and after each 6 minutes of interval the pressure was reduced to 23 bar and lastly 13 bar. Then cold water supply valve of the machine was opened to allow the water flow through the machine so that the system cools down to the room temperature immediately after stopping the heat supply and gradually the pressure was also allows to down to zero and the mould was taken out from the chamber with prepared biodegradable sheet.

\section{Test for Biodegradable Sheet}

\section{Thickness of the Sheet}

Thickness is the most important parameter which has direct influence on tensile properties and puncture force (Galdeano et al., 2013). The testing was carried out by using thickness gauge. The prepared biodegradable composite sheets by chitosan and arrowroot starch were tested for thickness from three different dimensions to get the mean.

\section{Tensile Strength}

Tensile strength refers to the maximum load that a material can support without fracture when being stretched, divided by the original cross-sectional area of the material. Tensile strengths have dimensions of force per unit area and the measurement are expressed in units of pounds per square inch, often abbreviated to psi or MPA. When stresses less than the tensile strength are removed, the material returns to its original shape and size either completely or partially. The biodegradable composite sheet were obtained from chitosan and arrowroot starch and tested for tensile strength using texture profile analyser in which the exact tensile strength was measured according to ASTM D638 
which specifically designed for testing.

Plastics upto $14 \mathrm{~mm}$ of in thickness, and can be used to test any type of plastic samples within this defined thickness range. ASTM D638 testing is conducted on a Universal Testing Machine at a constant crosshead speed. The measured tensile properties are UTS(MPA), Elongation, Max\%, Break (MPA), Elastic modulus (MPA). The above mentioned data were collected during the test of two samples $\mathrm{T}_{1}$ and $\mathrm{T}_{2}$.

\section{Test for Biodegradability}

Waste Reduction is a big challenge now days. Plastic makes up around 13 percent of the waste stream, representing 32 million tons of waste. Biodegradable plastics also help conserve petroleum supplies. Bioplastics are important in helping consumer goods companies present their brands in a favourable light. Recyclable or compostable packaging made from biological materials can be used to make their products more environmentally friendly in the eyes of consumers. In biodegradation process biodegradable plastics breaks down with the help of microorganisms into carbon dioxide, methane, water and biomass. The biodegradability test was done to know the impact on environment. The main aim was to achieve the degradability of the prepared biodegradable sheet. For this, the samples were buried in the soil. The test was performed with some modifications as per the following paper (Rachamawati et al., 2015), (Azahari et al., 2011) and (Thakore et al., 2001). A large bucket was filled with the soil and the samples were cut into definite sizes of square pieces and buried in the soil at a depth of $10 \mathrm{~cm}$. The bucket was placed in a room under at $25^{\circ} \mathrm{C}$ temperature and 50-60\% of humidity for upto one month. The moisture of the soil was maintained by sprinkling water into it at regular intervals of time. The degradation of the samples was determined at second and fourth week of intervals by carefully removing the samples from the bucket and washing them to remove the soil from it and the samples were dried at $45-$ $50^{\circ} \mathrm{C}$ upto $1.5-2$ hours, so that the samples were dried properly. The weight loss of the sample over the time was used to indicate the degradation rate of soil burial test. And the weight loss \% was calculated according to the Eq. 3.1 to show the amount of biodegradation done.

\section{Weight loss \\ $=\frac{(\text { Initial weight }- \text { Final weight })}{\text { lnitial weight }} \times 100$ ...Eq. 3.1}

\section{Results and Discussion}

Various results obtained for this study is summarized in the below headings.

\section{Evaluation of Properties of Biodegradable Sheet}

\section{Sheet Thickness and Tensile properties}

Uniform thickness is preferable for any plastic film or sheet. The thickness was measured at three different points of each sample. The mean thickness was then calculated using gauge and mean thickness of $T_{1}$ is $1.171 \mathrm{~mm}$ and $\mathrm{T}_{2}$ is $1.206 \mathrm{~mm}$.

All the readings are shown in the Table 4.2 and are Graphically plotted in Graph 4.3. Approximate results were obtained in the studies conducted by Sadhu et al., (2014), whose work was on preparation of Starchchitosan blend sheet and study of its mechanical properties, according to Siddaramaiah et al., (2003). From the ANOVA analysis of Table 4.2, it can be concluded that significant effect of treatments on thickness of samples were observed. Tensile properties are shown in the Table 4.3. 
Table.1 Experimental Plan

\begin{tabular}{lcl}
\hline VARIABLES & LEVEL & DESCRIPTION \\
\hline Product & $\mathbf{1}$ & Biodegradable Sheet \\
Method & $\mathbf{1}$ & Compression Moulding Methods \\
Constituents & $\mathbf{4}$ & $\begin{array}{l}\text { Chitosan, Arrowroot Starch, } \\
\text { Citric Acid \& Glycerol } \\
\text { Treatments }\end{array}$ \\
Mechanical Properties & $\mathbf{2}$ & $\mathrm{T}_{1}, \mathrm{~T}_{2}$ \\
Degradability Test & $\mathbf{2}$ & Thickness, Tensile Strength \\
Replications & $\mathbf{1}$ & Soil Degradability Test \\
& $\mathbf{3}$ & Three replications
\end{tabular}

Table.2 Different Composition of Biodegradable Sheet

\begin{tabular}{cccccc}
\hline TREATMENT & $\begin{array}{c}\text { CHITOSAN } \\
(\mathbf{\%})\end{array}$ & $\begin{array}{c}\text { STARCH } \\
(\mathbf{\%})\end{array}$ & $\begin{array}{c}\text { GLYCEROL } \\
(\mathbf{g})\end{array}$ & $\begin{array}{c}\text { CITRICACID } \\
(\mathbf{g})\end{array}$ & $\begin{array}{c}\text { WATER } \\
(\mathrm{ml})\end{array}$ \\
\hline $\mathrm{T}_{\mathbf{l}}$ & 50 & 50 & 35 & 3 & 45 \\
$\mathrm{~T}_{\mathbf{2}}$ & 30 & 70 & 35 & 3 & 45 \\
\hline & & & & & \\
F- test & $\mathrm{S}$ & $\mathrm{S}$ & $\mathrm{S}$ & $\mathrm{S}$ & $\mathrm{S}$ \\
\hline S. Ed. $( \pm)$ & & & & & \\
C. D. $(\mathbf{P}=\mathbf{0 . 0 5})$ & 1.765 & 1.495 & 1.706 & 0.397 & 0.255 \\
\hline
\end{tabular}

$\mathrm{S}=$ Significant 
Int.J.Curr.Microbiol.App.Sci (2021) 10(09): 216-229

Table.3 Tensile Strength Properties

\begin{tabular}{|c|c|c|c|c|c|}
\hline Treatment & Batch & Dimension(mm) & Thickness(mm) & $\begin{array}{l}\text { Tensile } \\
\text { (MPa) }\end{array}$ & $\begin{array}{c}\text { Elongation at } \\
\text { Break }(\%)\end{array}$ \\
\hline \multirow[t]{3}{*}{$\mathbf{T}_{1}$} & 1 & $30 \times 80$ & 1.18 & 5.62 & 143 \\
\hline & 2 & $30 \times 80$ & 1.15 & 4.32 & 168 \\
\hline & 3 & $30 \times 80$ & 1.20 & 4.48 & 156 \\
\hline Mean & & $30 \times 80$ & 1.17 & 4.80 & 155.6 \\
\hline \multirow[t]{3}{*}{$\mathbf{T}_{2}$} & 1 & $30 \times 80$ & 1.19 & 3.46 & 218 \\
\hline & 2 & $30 \times 80$ & 1.21 & 4.19 & 189 \\
\hline & 3 & $30 \times 80$ & 1.22 & 3.58 & 203 \\
\hline Mean & & $30 \times 80$ & 1.20 & 3.74 & 203.3 \\
\hline F- test & & & $\mathrm{S}$ & $\mathrm{S}$ & $\mathrm{S}$ \\
\hline S. Ed. $( \pm)$ & & & 0.006 & 0.168 & 4.035 \\
\hline C. D. $(P=0.05)$ & & & 0.013 & 0.357 & 8.555 \\
\hline
\end{tabular}


Fig.1

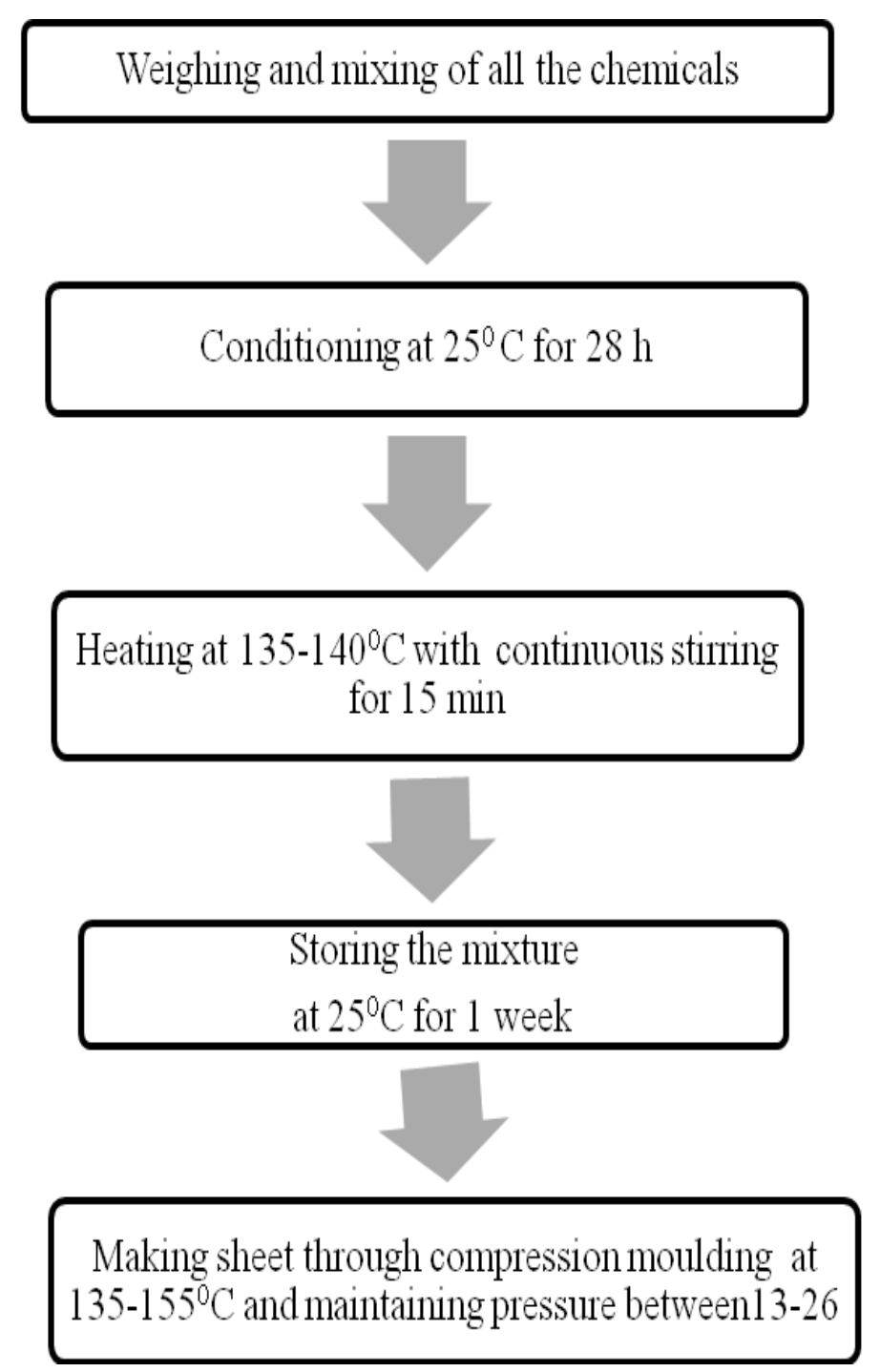


Int.J.Curr.Microbiol.App.Sci (2021) 10(09): 216-229

Fig.2 Prepared biodegradable sheet

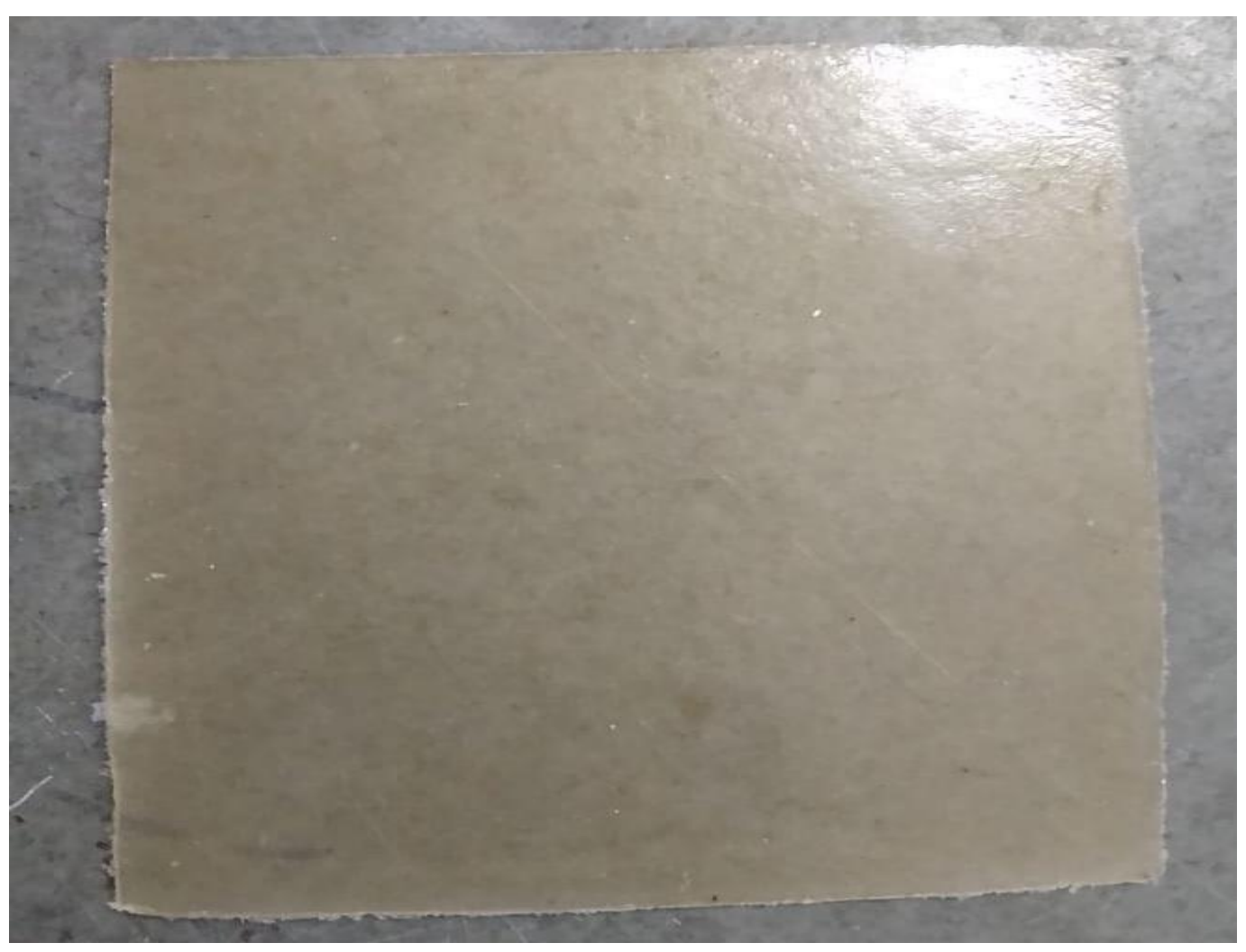


From ANOVA analysis of tensile strength Table 4.3 , it is evident that the calculated value of $\mathrm{F}$ due to treatment is smaller than the tabulated value at $5 \%$ probability level.

Therefore it can be concluded that significant effect of treatment on tensile strength of samples were observed. ANOVA analysis of Elongation at break (\%) (Table 4.3) also showed that there were significant effect of treatment on Elongation at break (\%) of samples.

\section{Test for Biodegradability}

After preparation of the sheet, Biodegradability test was carried out to check the biodegradability property of the sheet which was obtained by compression moulding.

To check the biodegradability, Soil burial test was carried out in which initial weight was taken before putting into the soil and then weight was taken after $2^{\text {nd }}$ and $4^{\text {th }}$ week after preparation of the sheet and the weight loss calculated by the below mentioned formula

$$
\begin{aligned}
& \text { Weight loss } \\
& =\frac{(\text { Initial weight }- \text { Final weight })}{\text { Initial weight }} \times 100
\end{aligned}
$$

All the readings of the degradation are shown in the Table 4.4. Result showed that sample $\mathrm{T}_{2}$ showed the higher percentage of weight loss, i.e. $19 \%$ and $\mathrm{T}_{1}$ has the lower percentage of weight loss, i.e.13\% after 4 weeks. The values were represented graphically in the Fig 4.6 shows degradability after four week of observation. From ANOVA analysis of biodegradability study Table 4.4 , it can be concluded that there is significant effects of treatments and days on biodegradability, However replication of each treatment have no significant effects on biodegradability.
Biodegradable polymers will have a greater role in the packaging sector. Biodegradable plastics and other biodegradable or compostable materials like paper, food and garden waste are generally unsuitable for landfill due to their potential to release methane under anaerobic conditions. Biodegradable bio plastics are more suitable for biological waste treatment through industrial and/or domestic composting and, subject to further demonstration, potentially in anaerobic digestion systems. Petroleum polymer should be replaced with biopolymer to save the environment and to maintain the ecosystem properly. However, biodegradable polymers can-not be solely used and must be blended with other biodegradable additives to enhance their mechanical properties and shape stability. Although the properties of chitosan and arrowroot starch blend films containing different plasticizers. However new additives should be introduced to support bio based packaging material production. In this research, compression moulding technique was used to produce the biodegradable sheet by chitosan and arrowroot starch. Generally casting method is practised mostly to produced biodegradable packaging film or sheet but in terms of bulk production we should focus on bulk amount of production by extrusion method for continued and bulk amount of production but in that case more research is needed to increase the strechibility. Looking onto the situation compression moulding technique had been used which is also a important production technique for plastic and it also can be used for commercial production as like extrusion technique.

Chitosan and arrowroot starch biodegradable polymer sheet was obtained with glycerol and citric acid and water through compression moulding method.

All the prepared sheets were evaluated for thickness, tensile strength and 
biodegradability.

Thicknesses of the both sheet were 1.17 and $1.20 \mathrm{~mm}$.

Tensile strengths of the both sheet were 3.74 MPA and 4.80MPA. Sheet denoted as $\mathrm{T}_{1}$ has the higher tensile strength and compared as $\mathrm{T}_{2}$. Elongation at break $\%$ of the both sheet were $155.6 \%$ and $203.3 \%$. Sheet denoted $\mathrm{T}_{1}$ has the lowest elongation at break $\%$ and sheet labelled $\mathrm{T}_{2}$ has the highest.

Performance evaluation of biodegradable films was done by soil burial method for 30 days at an interval of 15 days. Sheet denoted $\mathrm{T}_{2}$ has the highest percentage of decomposition, i.e. $19 \%$ after 30 days.

Chitosan and arrowroot starch biodegradable composite sheet was obtained in two proportions $T_{1}$ and $T_{2}$ with three replications of each through compression moulding method.'

Mechanical properties of $T_{1}$ shown better result as compared to the $T_{2}$ in which chitosan and starch was taken in equal proportions

Elastic modulus of $T_{2}$ was greater than $T_{1}$.

Biodegradability of the sample $\mathrm{T}_{2}$ also showed better result compared to the sample $\mathrm{T}_{1}$.

There are a large number of sectors where biodegradable plastics may find use. All sectors require environmentally friendly polymers. Because the level of biodegradation may be tailored to specific needs, each industry is able to create its own ideal material. The Environmental responsibility is constantly increasing in importance to both consumers and producers. For the producers and researchers biodegradable plastic materials, this is a key advantage. Biopolymers limit carbon dioxide emissions during creation, and degrade to organic matter after disposal. Although synthetic plastics are a more economically feasible choice than biodegradable ones, an increased availability of biodegradable plastics will allow many consumers to choose them on the basis of their environmentally responsible disposal. Biodegradable plastics containing starch and/or cellulose fibres or chitosan appear to be the most likely to experience continual growth in terms of demand. Microbiologically grown plastics are scientifically sound, and a novel idea, but the infrastructure needed to commercially expand their use is still costly, and inconvenient to develop. Time is of the essence for biodegradable polymer development, as society's current views on environmental responsibility make this an ideal time for further growth of biopolymers. From this research it can be concluded that chitosan and arrowroot starch can be a good combination for making biodegradable plastics as arrowroot starch is less expensive and easily available in anywhere. It is also felt that more research also needed to increase its tensile properties to make it more versatile.

\section{References}

Aprianita A., Todor V., Anna B. \& Stefan K., 2014, Physicochemical properties of flours and starches derived from traditional Indonesian tubers and roots, Journal of Food Science and Technology, volume 51, pages36693679

Arbia W., Arbia L., Adour L., Amrane A., 2013, Chitin Extraction from Crustaceans Shells Using Biological Methodes- A Review, ISSN 13309862(FTB-2839), Chitin Recovery Using Biological Methods, Food Technol. Biotechnol. 51 (1) 12-25

Ashraf Shafia, 2019, Bio plastics for Food Packaging : A Review, International Journal of Current Microbiology and 
Applied Sciences, ISSN:2319-7706

Volume 8 Number 03 Journal homepage: http://www.ijcmas.com

Azahari N. A., Othman N., Ismail H., 2011, Biodegradation Studies of Polyvinyl Alcohol/Corn Starch Blend Films in Solid and Solution Media, Journal of Physical Science, Vol. 22(2), 15-31

Basiak E., Lenart A., and Debeaufort F., 2017. Effect of starch type on the physicochemical properties of edible films. International Journal of Biological Macromolecules, 98, 348-356. doi:10.1016/j.ijbiomac.2017.01.122.

Benahabiles M. S., Salah R., Lounici H., Drouiche N., Goosen M. F. A, Mameri N., 2012, Antibacterial activity of chitin, Chitosan and its oligomers prepared from shrimp shell waste, Food Hydrocolloids, Elsevier Volume 29, Pages 48-56

Bhagat P. H., Pandharipande S. L, 2016, LIT, Nagpur: "Synthesis of chitin from crab shells and its utilization in preparation of nanostructured film”, ISSN: 2278-7798 International Journal of Science, Engineering and Technology Research (IJSETR) Volume 5

Brodnjak U. V., Todorova D., 2018, Chitosan and Rice Starch Films as Packaging Materials, https://doi.org/10.24867/GRID-2018p34

Caisa J., Julien B., Iñaki M., Petronela N., David P., Peter Š., Diana G. S., Sanna V., Marco G. B., Chris B., Francis C., Susana A., 2012, Renewable fibers and bio-based materials for packaging applications - A review of recent developments, 10.15376/biores.7.2.2506-2552

Dang K. M., \& amp; Yoksan, R., 2014, Development of thermoplastic starch blown film by incorporating plasticized chitosan, Carbohydrate Polymers,115, 575 581.http://dx.doi.org/10.1016/j.carbpol.2 014.09.005

Ezeoha S. L, Ezenwanne J. N, 2013, Production of Biodegradable Plastic Packaging Film from Cassava Starch, IOSR Journal of Engineering(IOSRJEN) e-ISSN: 2250-3021, p-ISSN: 2278-8719 Vol. 3, ||V5|| PP 14-20

Gadekar T Pradeep, Mahanwar A Prakash, Das Abhijit, Gadhave V Ravindra, 2018, Starch Based Bio plastics: The Future of Sustainable Packaging, Open Journal of Polymer Chemistry, Vol 8 No. 2

Gadhave R. V., Das A, Mahanwar P. A., Gadekar P. T., 2018, Starch Based BioPlastics: The Future of Sustainable Packaging, Open Journal of Polymer Chemistry, 2018, 8, 21-33, ISSN Online: 2165-671

Giyatmi, Milanie S, Fransiska D, Dharamawan M, Irianto H E, 2017, Barrier And Physical Properties Of Arrowroot Starch-Carrageenan Based Biofilms, Bio Sci 25:45-56

Guerrero P., Muxika A., Zarandona I., de la Caba K., 2018, Cross linking of chitosan films processed by compression molding, Carbohydrate Polymers 206, $820-860$

Herrera Natalia, Roch Hendrick, Salaberria Asier M., Pino-Orellana Maximiliano A., Jalel Labidi, Fernandes Susana C. M, Radic Deodato, Leiva Angel, Oksman Kristiina, 2016, Functionalized blown films of plasticized polylactic acid/chitin nanocomposite: preparation and characterization, Materials and Design, Elsevier, Materials and Design 92, 846852

Hiremani V., Gasti T., Satareddi S., Vanjeri V., Goudar N., 2020, Characterization of Mechanical and Thermal Properties of Glycerol Mixed Oxidized Maize Starch/Polyvinyl alcohol Blend Films, DOI: 10.1016/j.cdc.2020.100416

Jessica I. Lozano-Navarro, Nancy P. Diaz- 
Zavala, Carlos Velasco-Santos, Jose A. Melo-Banda, Ulises Paramo-Garcia, Francisco Paraguay-Delgado, Ricardo Garcia-Alamilla, Ana L. MartinezHernandez and Samuel Zepien-Castillo, 2018, Chitosan-Starch Films with Natural Extracts: Physical, Chemical, Morphological and Thermal Properties, Materials (Basel), PMC5793618

Kumar K., Immanuel G., 2019, Effect of potato starch on LDPE and its suitability as food packaging film, International Journal of Chemical Studies 2019; 7(5): 2424-2428

Leceta, I., A. Etxabide, S. Cabezudo, K. de la Caba, P. Guerrero, 2014,Bio-basedfilms prepared with by-products and wastes: environmental assessment, Journal of Cleaner Production, DOI: 10.1016/j.jclepro.2013.07.054

Leceta, I., P, Guerrero K. de la Caba, 2013, Functional properties of chitosan-based films, Carbohydrate Polymers 93 (2013) 339- 346

Leceta, I., S. Molinaro, P. Guerrero, J.P. Kerry, K. de la Caba., 2015, Quality attributes of map packaged ready-to-eat baby carrots by using chitosan-based coatings. Postharvest Biology and Technology; 100: 142DOI: 10.1016/j.postharvbio.2014.09.022

Liu, M., Huang, Z., and Yang, Y.-J. (2010). Analysis of Biodegradability of Three Biodegradable Mulching Films. Journal of Polymers and the Environment, 18(2), 148-154.

Lopez O, Garcia A M, Villar M A, Gentilli A, Rodriguez M. S, Albertengo L, 2014, Thermo Compression Of Biodegradable Thermoplastic Arrowroot Starch Films Containing Chitin And Chitosan, Elsevier, LWT 106-115

Lorenz Antony T. Fernendo, Myra Ruth S. Poblete, Aileen Grace M. Ongkiko, Lesilie Joy L. Diaz, 2016, Chitin Extraction and Synthesis of Chitin-
Based Polymer Films From Blue Swimming Crab (Portunus pelagicus)Shells, Elsevier, Procedia Chemistry 19, $462-468$

Lu D. R, Xiao C. M, Xu S. J, 2009, Starchbased completely biodegradable polymer materials, express Polymer Letters Vol.3, No.6,366-375 Available online at www.expresspolymlett.com DOI: 10.3144/expresspolymlett.2009.46

Navarro Y. M., Soukup K., Jandová V., Gómez M. M., Solis J. L., Cruz J. F., Siche R., Šolcová O., Cruz G. J. F., 2008, Starch/chitosan/glycerol films produced from low-value biomass: effect of starch source and weight ratio on film properties, J. Phys.: Conf. Ser. 1173 012008

Nogueira Ferreira Gislain, Fakhouri Matta Farayde, Oliveira Augustusde Rafael, 2018, Extraction and characterization of arrowroot (Marantaarundinaceae L.) starch and its application in edible films, Carbohydrate Polymers, Elsevier, Pages 64-72,Volume 186

Park, S. Y., K. S. Marsh, J. W. Rhim, 2002, Characteristics of different molecular weight chitosan films affected by the type of organic solvents, Journal of Food Science, 67 (1), pp. 194-197, 10.1111/j.1365-2621.2002.tb11382.

RahmanRukshana, Sood Monika, Gupta Neeraj, Bandral Julie D., Hameed Fozia and Ashraf shafia,2019, Bioplastics for Food Packaging: A Review, International Journal of Current Microbiology and Applied Sciences ISSN: 2319-7706 Volume 8 Number 03

Reddy, N., and Yang, Y. (2010). Citric acid cross-linking of starch films. Food Chemistry, 118(3), 702-711. doi:10.1016/j, foodchem.2009.05.050.

Roz, A., Carvalho, A., Gandini, A., and Curvelo, A. (2006). The Effect Of Plasticizers On Thermoplastic Starch Compositions Obtained By Melt 
Processing, Carbohydrate Polymers, 63(3), 417-424.

Rungsiri Suriyatem, Auras Rafael A., Chitsiri Rachtanapun and Pornchai Rachtanapun, 2018, Biodegradable Rice Starch/Carboxymethyl Chitosan Films with Added Propolis Extract for Potential Use as Active Food Packaging, Polymers (Basel). 10(9): 954, doi: 10.3390/polym10090954

Seligra, P. G., Medina Jaramillo, C., Fama, L., and Goyanes, S. (2016). Biodegradable and non-retrogradable eco-films based on starch-glycerol with citric acid as cross linking agent, Carbohydrate Polymers, 138, 66-74.

Shah S., Immanuel G., Mathur S., 2019, Effect of corn starch on LDPE and its suitability as food packaging film, International Journal of Chemical Studies 2019; 7(4): 1352-1355

Siakeng, R.; Jawaid, M.; Ariffin, H.; Sapuan, S., 2018, Thermal properties of coir and pineapple leaf fibre reinforced polylactic acid hybrid composites. In: IOP Conference Series: Materials Science and Engineering, IOP Publishing: Brisol, UK; p. 012019.

Sullca C. V., Lorena A., Vargas M., Chiralt A., 2018, Physical and Antimicrobial Properties of Compression-Molded Cassava Starch-Chitosan Films for Meat Preservation, Food and Bioprocess Technology 11:13391349https://doi.org/10.1007/s11947-0182094-5

Sunarti Chandra Titi, Febrian Irshan, M., Ruiani Eka, Yuliasi Indah, 2019, Some Properties of Chemical Cross-Linking Biohydrogel From Starch And Chitosan, Volume 2019 |Article ID 1542128 | https://doi.org/10.1155/2019/1542128

Suriyatem R., Auras R. A., Rachtanapun C., Rachtanapun P., 2018, Biodegradable Rice Starch/Carboxymethyl Chitosan
Films with Added Propolis Extract for Potential Use as Active Food Packaging, Polymers2018,10, 954;

doi:10.3390/polym10090954www.mdpi. com/journal/polymers

Takegawa, Murakami M, Kanejo Y, Kadokawa J., 2010, Preparation of chitn/cellulose composite gels and films with ionic liquids, Carbohydrate Polym 79: $85-90$

Tang, X., and Alavi, S. (2011). Recent advances in starch, polyvinyl alcohol based polymer blends, nanocomposites and their biodegradability. Carbohydrate Polymers, 85(1), 7-16. doi:10.1016/j.carbpol.2011.01.030.

Thaiwen B., Chinnan M. S., 2008, Preparation and properties of rice starch-chitosan blend biodegradable film, Food Science and Technology, Volume 41, Issue 9, November 2008, Pages 1633-1641

Thakore I. M., Desai S., Sarawade B. D., Devi S., 2001, Studies on biodegradability, morphology and thermo-mechanical properties of LDPE/modified starch blends, European Polymer Journal 37(1):151-160

Tharanathan R. N., 2003, Biodegradable films and composite coatings: Past, present, and future, Trends in Food Science and Technolog,Elsevier, Vol 14,71-78.

Thunwall Mats, Boldizer Antal, Rigdahi Mikael, 2006, Extrusion processing of high amylase potato starch materials, Carbohydrate Polymer 11: 419-428.

Wang Hongxia, Qian Jun, Ding Fuyuan, 2018, Emerging Chitosan-Based Films for Food Packaging Applications Hongxia Wang, Agric. Food Chem.,66, 395-413

Yoon, S.-D. (2013). Cross-Linked Potato Starch-Based Blend Films Using Ascorbic Acid as a Plasticizer. Journal of Agricultural and Food Chemistry, 62(8), 1755-1764. 


\section{How to cite this article:}

Abhirup Mitra and Genitha Immanuel. 2021. Biodegradable Sheet from Chitosan and Arrowroot Starch by Compression Moulding and its Properties. Int.J.Curr.Microbiol.App.Sci. 10(09): 216-229. doi: https://doi.org/10.20546/ijcmas.2021.1009.025 